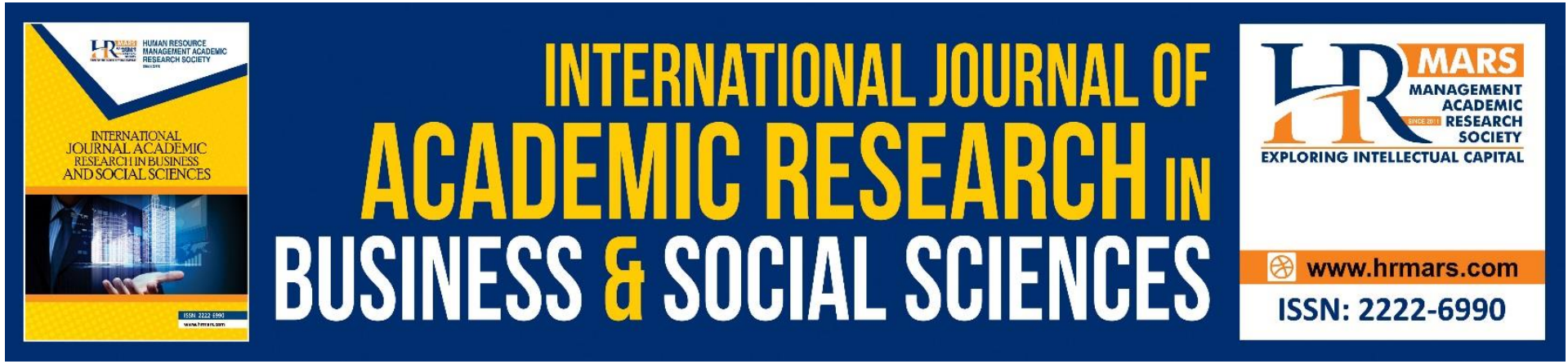

\title{
Cognitive, Psychomotor and Affective Analysis for Industrial Training of Faculty Plantation and Agrotechnology 's Students
}

Fatin Khairuddin, Nordiana Ibrahim, Salwa Adam

To Link this Article: http://dx.doi.org/10.6007/IJARBSS/v11-i10/11435

DOI:10.6007/IJARBSS/v11-i10/11435

Received: 08 August 2021, Revised: 02 September 2021, Accepted: 27 September 2021

Published Online: 18 October 2021

In-Text Citation: (Khairuddin et al., 2021)

To Cite this Article: Khairuddin, F., Ibrahim, N., \& Adam, S. (2021). Cognitive, Psychomotor and Affective Analysis for Industrial Training of Faculty Plantation and Agrotechnology's Students. International Journal of Academic Research in Business and Social Sciences, 11(10), 718-726.

Copyright: (c) 2021 The Author(s)

Published by Human Resource Management Academic Research Society (www.hrmars.com)

This article is published under the Creative Commons Attribution (CC BY 4.0) license. Anyone may reproduce, distribute, translate and create derivative works of this article (for both commercial and non-commercial purposes), subject to full attribution to the original publication and authors. The full terms of this license may be seen at: http://creativecommons.org/licences/by/4.0/legalcode

Vol. 11, No. 10, 2021, Pg. $718-726$

Full Terms \& Conditions of access and use can be found at http://hrmars.com/index.php/pages/detail/publication-ethics 


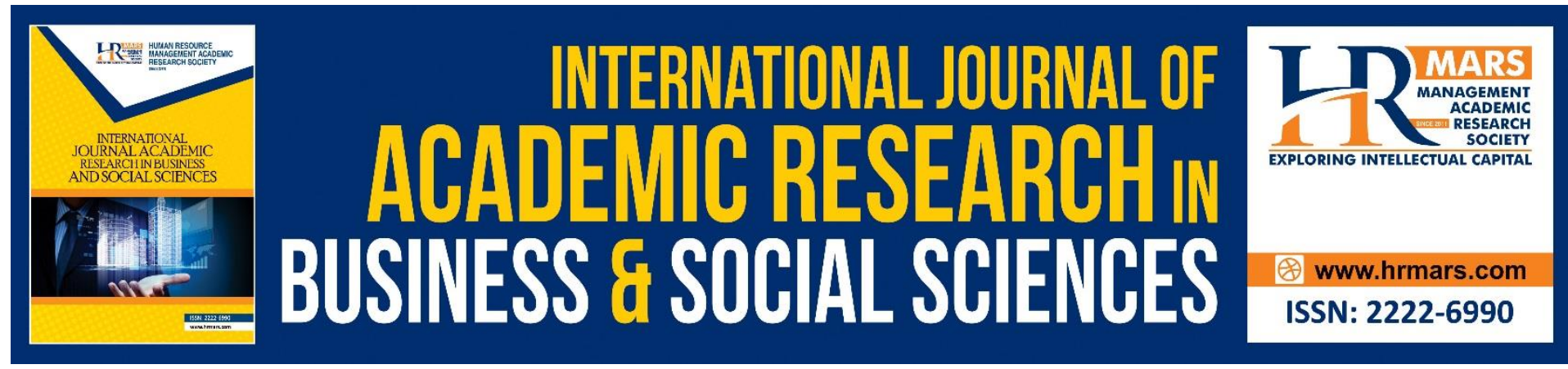

\title{
Cognitive, Psychomotor and Affective Analysis for Industrial Training of Faculty Plantation and Agrotechnology 's Students
}

\author{
Fatin Khairuddin, Nordiana Ibrahim, Salwa Adam \\ Faculty of Plantation and Agrotechnology, Universiti Teknologi MARA (UiTM) Cawangan \\ Melaka Kampus Jasin \\ Email: fatinkhairuddin@uitm.edu.my
}

\begin{abstract}
The industrial training is a valuable component of a university's curriculum that enhances the soft skills of graduates. This is a part of the syllabus for all students who enroll under the Faculty of Plantation and Agrotechnology, Universiti Teknologi MARA. The goal of industrial training is to expose the students to the real working conditions. Thus, the research aim is to measure and compare the students' skill sets before and after they completing their industrial training. A quantitative research method used to achieve the research objectives and the data collection conducted among the students after they have completed 6-8 weeks of industrial training in the industry. The primary data collected using questionnaire from 196 samples from diploma and bachelor degree program in the faculty through simple random sampling method. The result found that the average performance of the students before the industrial training is $61.6 \%$ of the cognitive (thinking), $62.3 \%$ of the psychomotor (skill) and $70.8 \%$ of affective (ethic). After completing the industrial training, these three parameters increased to $78.9 \%$ of the cognitive, $83.9 \%$ of the psychomotor and $84 \%$ of affective. Referring to the T-test analysis in SPSS, the finding expected to reveal that there is significance different on the cognitive, psychomotor and affective domain before and after completing industrial training since the $p$ value is 0.00 less than 0.05 . As a conclusion, during industrial training students showed high level of performance achieved, which helped improving their soft skill and competencies also help in reducing the unemployable rate among the graduate students.
\end{abstract}

Keywords: Affective, Cognitive, Industrial Training, Learning Domain, Psychomotor.

\section{Introduction}

The scenario of working environment nowadays is very competitive and challenging. Students have to prepare themselves with a good skill set to ensure they can be accepted in the workplace and help to reduce unemployment among them. One of the ways to improve the students' skill set by exposure them with real work environment through industrial training. The industrial training is a part of university requirement to expose the students with professional skills and experiences in plantation practices and preparing the students for the real working environment. The objectives of conducting industrial training are to enhance students' knowledge in one particular area, increase self-confidence of students, helps in 
finding their own proficiency and to cultivate the student's leadership ability and responsibility to perform or execute the given task. Kamarulzaman et al, 2011 stated that $91 \%$ of respondents 'agreed' that the industrial training able to increase their career opportunities while $88 \%$ also believed this training provides the qualifications for several careers after graduation. $92 \%$ of the respondents agreed that the industrial training provides guidance for their future careers.

Besides, the aims of industrial training are to meet the tertiary level of education and to produce excellent graduates who not only had excelled in their field of study, but also equipped with the necessary of soft skill knowledge, leadership ability and critical thinking abilities (MOHE 2015). Higher learning institutions are now providing students with the opportunity to translate the knowledge gained into practice through industrial training, also known as practical training or internship. According to the Wodi and Dokubo (2009) opined that if industrial training is not adequately implemented, it becomes difficult for graduates to secure employment in the occupation or make a smooth transition from schools to work. While students are still at university, an internship can help them develop a core of global market skills that are now considered requirements, such as communication and time management skills, better self-confidence and better self-motivation (Gill and Lashine, 2003). Work experience through a co-operative program provides credible means for softening the reality shock of transitioning from the world of academics to the working world. (Garavan and Murphy, 2001; Collin and Tynjalla, 2003). In fact, internships increase job opportunities for students since it allows them to improve their job skills and work values, focus on their career choices, directly access job sources, even to impress potential employers.

The students conducted industrial training in the first and second year approximately around 6-8 weeks per semester during semester break. This training is compulsory for all students from Faculty of Plantation and Agrotechnology which they must completed two (2) times during 3 years full time study. The survey was conducted before and after the students completing their industrial training. The students have been undergoing for industrial attachment from various government and private agencies such as Sime Darby Plantation Berhad, IOI Plantation Berhad, FELDA, Felcra Plantation, Kulim Plantation, MARDI and etc . The aims of this study are to compare the learning domain in bloom's taxonomy which are cognitive, psychomotor and affective before and after completing the industrial training. According to Oladele et al, 2011 comparison before and after practical training among students showed that, there are significant differences were found among 32 tasks with students having higher competence mean score after the FPT training than the score before the training in agricultural sector

\section{Bloom's Taxonomy of Learning Domains}

The parameter used for the study are cognitive, psychomotor and affective is a great component to analyze the output after competing industrial training. This categorization is best explained by the Taxonomy of Learning Domains formulated by a group of researchers led by Benjamin Bloom along with in 1956. Studies by Benjamin Bloom (on cognitive domain), David Krathwohl (affective domain) and Anita Harrow (Psychomotor domain) have been encompassed into the three domains of learning (Sousa, 2016). 


\section{Cognitive Domain}

The cognitive domain includes a demonstrable acquisition of specific knowledge and skill. The cognitive domain contains learning skills predominantly related to mental (thinking) processes. Learning processes in the cognitive domain include a hierarchy of skills involving processing information, constructing understanding, applying knowledge, solving problems, and conducting research. According to (Kamarulzaman et al, 2010) reported that the knowledge of the students was increased from $41 \%$ to $89 \%$ after they completed industrial training.

\section{Psychomotor Domain}

Psychomotor domain involves physical movement coordination, and use of the motor skill area. Development of this skill requires practice and is measured in term of speed, precision, distance, procedure and technique (Mohd, 2008). In recruiting new employees, the job market has ever emphasized on working experience in addition to the paper qualification, thus the requirement makes working experience or industrial training becomes fundamental in the learning institutions (Saat and Ahmad, 2009). Lim and Muszafarshah, 2013 stated that training is a effective ways in improving communication, creative and analytical, time and management skills.

\section{Affective Domain}

Affective domain is considerable interest how have their college experience impacted students' value goals, attitude, self-concept, worldview and behavior. The affective domain involves our feelings, emotions, and attitudes. This domain includes the manner in which we deal with things emotionally, such as feelings, values, appreciation, enthusiasms, motivations, and attitudes (Hoque, 2016)

\section{Research Methodology}

Type of Respondents

This study was a quantitative research design through a descriptive survey that described the effectiveness of industrial training on FPA students, which conducted at Universiti Teknologi MARA, Melacca Branch, Jasin Campus. Structured questionnaires from the literature were used to collect primary data from the students who participated in the industrial training in August 2017. The questionnaire comprised of two main sections which the first section focused on students' profile and the second intended to assess the effectiveness of industrial training. The parameter for the study are cognitive, psychomotor and affective as independent variables and students result is a dependent variable were collected before and after participating the industrial training.

\section{Population and Sample Size}

According to the Krejcie and Morgan, 1970 table, the students involved in this study were from 140 diploma students and 120 bachelor degree students with the sample size is 104 and 92 respectively. So total sample size is 196 students' participation have been collected through simple random sampling. Assessment is carried out based on the Likert scale scores, namely 1, 2, 3, 4 and 5 which represent 'very weak', 'weak', 'fair', 'good' and 'very good' respectively. 


\section{Data Analysis}

Data from the questionnaire were evaluated using the software Statistical Package for the Social Science (SPSS) version 20. Descriptive analysis used to summarize the characteristics of the data and T-test analysis used to determine the significant differences between the means of two groups in measuring competence levels of students after completing industrial training.

\section{Theoretical Framework}

The Theoretical framework is a logical structural representation of the concepts, variable of dependent and independent and relationship involved in this study. Their function is to identify what needs to be measured, examined, explored and described. The Theoretical framework is important to guide and ensure the study is managed well. So that the researcher will identify whether a dependent and independent variable is related or not at the end of the study. A dependent variable for this study is the students' academic result while the independent variable are cognitive (thinking), psychomotor (skill) and affective (ethic) of learning domains.

\section{Results and Discussions}

Demographic characteristics of respondents

Table 1: Demographic characteristics of respondents

\begin{tabular}{|lll|}
\hline Variables & Frequency & Percentages \\
\hline Gender & 112 & \\
Male & 84 & 57.14 \\
Female & 196 & 42.86 \\
Total & & 100 \\
\hline Age & 0 & \\
$18-19$ & 108 & 0 \\
$20-21$ & 84 & 55.10 \\
$22-23$ & 4 & 42.86 \\
$24-25$ & 196 & 2.04 \\
Total & & 100 \\
\hline Education level & 92 & 46.94 \\
Degree & 104 & 53.06 \\
Diploma & 196 & 100 \\
\hline Total & & \\
\hline
\end{tabular}

Table 1 shows the demographic information about gender, age and educational level among the respondents was summarized. The respondents were 196 students from the Faculty of Plantation and Agrotechnology. Out of the 196 students, 57.14\% were male while $42.86 \%$ were females. A large proportion of the respondents (55.10\%) were between the ages of 20-21 years old. Also 104 of the respondents (53.06\%) were from diploma while 92 from degree students (46.94\%). 


\section{Descriptive Analysis on Learning Domains}

before_psychomotor

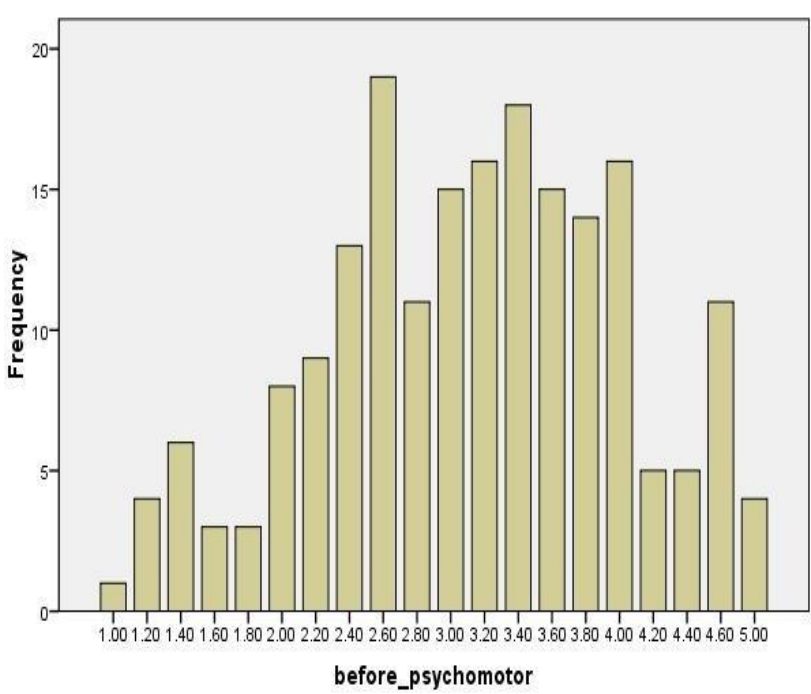

before_affective

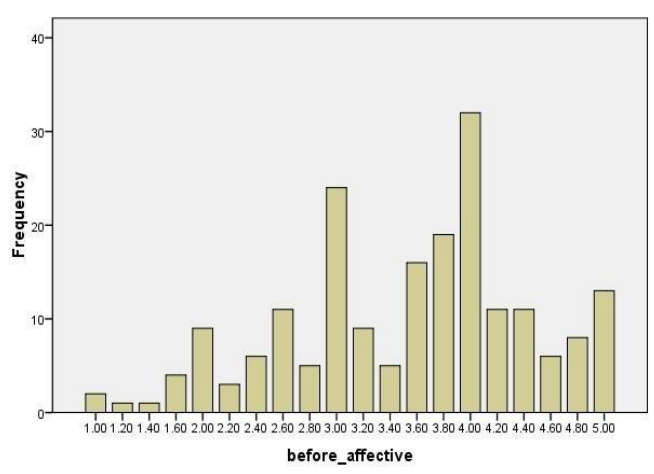

after_psycho

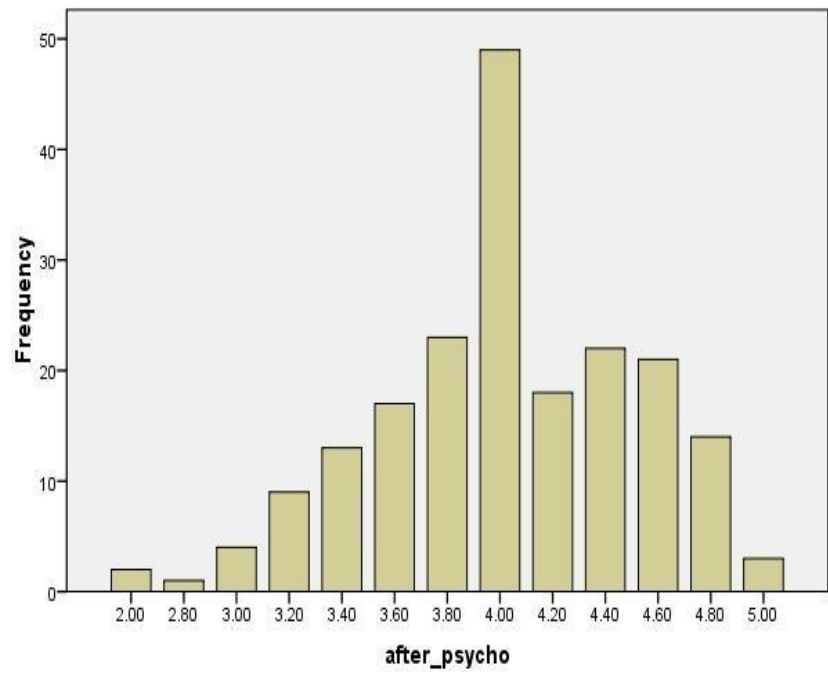

after_affect

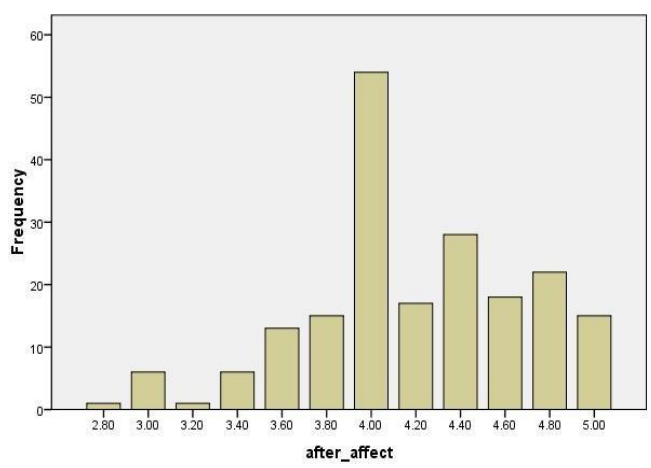

Figure 1: Descriptive analysis on learning domains

The bar chart in the figure 1 showed in detail the comparison before and after attending industrial training for each learning domains. All learning domains showed the increments in term of the value after they completed industrial training. The minimum value after completed industrial training were 2.00 which is weak score and the maximum value were 5.00 represent very good. It showed that even though the time duration for industrial training is very short about six week the students still can improves their skill, knowledge and attitude. 


\section{Comparison of Mean before and after Completed Industrial Training}

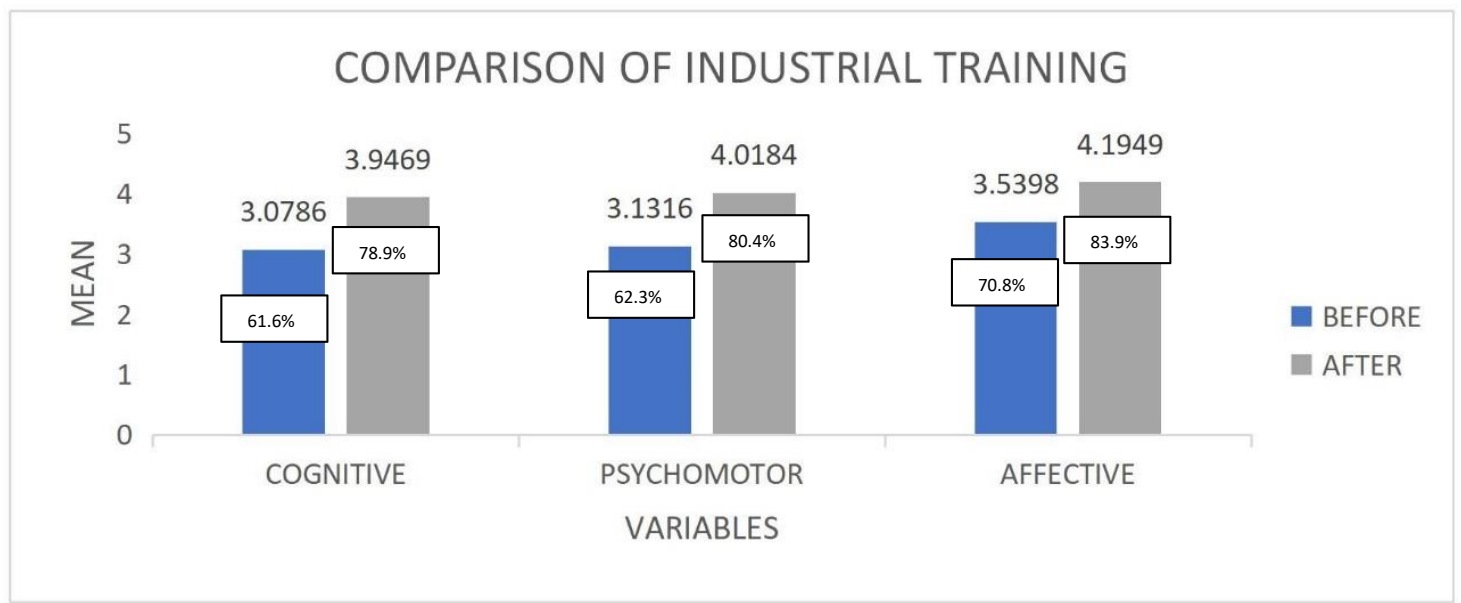

Figure 2: Mean of each learning domain before and after attending industrial training

Figure 2 presents the mean on the learning domain before and after attending industrial training. These mean differences used to do a comparison of industrial training and an overall improvement in the scores of 4 . The result showed that the mean of cognitive is 3.9469, psychomotor is 4.0184 and affective is 4.1949 after completed the industrial training. It was found that 'fair' score for cognitive domain recorded an increase by $17.3 \%$ from $61.6 \%$ to 78.9\%. While the 'good' score for psychomotor domain increased by $18.1 \%$ from $62.3 \%$ to $80.4 \%$. For the aspects of affective domain, there was an increment from $70.8 \%$ to $83.9 \%$ for a total increase of $13.1 \%$. This agrees with the finding of Ukwuoma and Akanwa (2008) who stated that effective training brings about an increase in knowledge required in the job, knowledge of the structure and business arms of the organization.

Paired T-Test for each Learning Domains

Table 2: Paired T-Test for each learning domains

\begin{tabular}{|l|l|l|l|l|l|}
\hline Variables SD & \multicolumn{1}{|c|}{ Mean } & df & Sig (2-tailed) \\
\hline $\begin{array}{l}\text { Before and After-.86837 } \\
\text { Cognitive }\end{array}$ & .89099 & -13.645 & 195 & 0.00 \\
\hline $\begin{array}{l}\text { Before and After-.88673 } \\
\text { Psychomotor }\end{array}$ & .95907 & -12.994 & 195 & 0.00 \\
\hline $\begin{array}{l}\text { Before and After-.65510 } \\
\text { Affective }\end{array}$ & 1.01022 & -9.079 & 195 & 0.00 \\
\hline
\end{tabular}

T-Test analysis is conducted to determine if there is a significant difference between before and after completing industrial training. Table 2 is the results of paired t-test showing the comparison before and after comple industrial training among students in terms of learning domains. The results showed that all of the variables in learning domains have significant differences since $p$ value is 0.00 less than 0.05 . This agrees with the findings of Mohd et al. (2009) who stated that, engineering students' perception after Industrial Training Placement in Malaysia showed beneficial effect and has significantly improved their 'personal attitude', 'communication', 'work attitude'. The experience gained has given them the opportunity to become better students and could, in the future, provide them with better employment 
prospects. According to the Lim and muszafar shah 2013 also stated that after attending industrial training, the respondents reported that their generic skills are more satisfactory ranging from 5.62 to 5.88 .

\section{Conclusion and Recommendation}

Industrial training is an effective way to improve the students' knowledge, skill and attitude. There are the significance differences between before and after completing industrial training even the time duration is limited. Relatively the most dominant learning is psychomotor which students learn and do hand on activities in their real working environment. They were able to use their learned knowledge in the actual work situation. Some weaknesses, particularly in terms of communication skills have been improved for which students will be more confident to communicate and thus adapt to their working environment. However, there are few areas need to be improved, particularly about the time duration of industrial training. Six to twelve months is very appropriate to the students to gain more benefits when attending industrial training. For the future studies is recommended to explore more learning domain received by the students during industrial training.

\section{References}

Ayarkwa, J., Adinyira, E., \& Osei, D. (undate). Industrial Training of Construction Students: Perceptions of Training Organizations in Ghana

Ena, B., Shahrina, M. N., \& Rohani, S. (2009).Internship Students' Workplace Communication Skills: Workplace Practices And University Preparation. Conference for Industry and Education Collaboration American Society for Engineering Education.

Gill, A., \& Lashine, S. (2003) Business education: a strategic market-oriented focus. International Journal of Education Management. Vol. 17 No. 5, pp. 188-94.

Hoque, M. E. (2016). Three Domains of Learning: Cognitive, Affective and Psychomotor. Journal Of EFL Education and Research (JEFLER). Volume 2 Number 2, ISSN-2520-5897.

Kamarulzama, M., Mohd, Z. O., Siti, A. O., Norhisham, T. K., Mohd, N. A. R., Maslina, J., \& Nordin, J. 2010). The Effectiveness of Industrial Training on UKM Engineering Students. Procedia Social and Behavioral Sciences 18 656-665.

Karunaratne, K., \& Perra, N. (2015). Students' Perception on the Effectiveness of Industrial Internship Programme.Proceedings of the International Conference on Global Business, Economics, Finance and Social Sciences. ISBN: 978-1-941505-22-9.

Kumar, S. (2015) Study on Present Scenario of Industrial Training for Students and The Suggestions for Further Improvement Through Defined Roles of Institute, Industry and Government. International Journal of Educational Planning \& Administration. ISSN 22493093 Volume 5, Number 1 (2015), pp. 1-6

Lim, H. E., \& Muszafarshah, M. M. (2013). Effectiveness Of Industrial Training in Improving Students' Generic Skills.International Journal of Business and Society.Vol. 14 No. 3, 2013, 368 - 375.

Meiching, C., Jianshen, C., \& Juiyuan, C. (2008). Determining The Effectiveness of Practical Training for Students of Universities of Technology in Taiwan: Empirical Findings Using a Structural Equation Model.International Journal of Innovative Computing. ISSN 13494198 Volume 4, Number 5.

Obasi and Rosemary. (2015). the impact of industrial training on students'academic performance. Journal of advances in social science research.Volume 2 No6.

Oladele, O. I., Subair, S. K., \& Thobega, M. (2011). Effectiveness of field practical training for 
competence acquisition among students of Botswana College of Agriculture.African Journal of Agricultural Research Vol. 6(4), pp. 923-930.

Ukwuoma, S. C., \& Akanwa, P. C. (2006). Human Resources Development programmes in Study of Universities in Imo State. Samaru Journal of Information Studies, 8(2): 38-47.

Wodi, S. W., \& Dokubo, A. (2009). Appraisal of Students Industrial Work Experience Scheme (SIWES) in five tertiary Institutions in Rivers State Nigeria. European Journal of Social Science. 7(3):42. 